\title{
Enhancing the benefits of girls' livelihood initiatives
}

\section{Sajeda Amin}

Population Council

Follow this and additional works at: https://knowledgecommons.popcouncil.org/departments_sbsr-pgy

Part of the Demography, Population, and Ecology Commons, Family, Life Course, and Society Commons, Gender and Sexuality Commons, and the International Public Health Commons How does access to this work benefit you? Let us know!

\section{Recommended Citation}

Amin, Sajeda. 2011. "Enhancing the benefits of girls' livelihood initiatives," Promoting Healthy, Safe, and Productive Transitions to Adulthood Brief no. 17. New York: Population Council. 


\title{
Enhancing the benefits of girls' livelihood initiatives
}

\author{
Prepared by Sajeda Amin
}

A s a pioneer in the relatively young field of adolescent livelihood programs, the Population Council has implemented and evaluated a range of projects that test vocational training, savings, financial education, and credit initiatives. Since the 1990s, the Council has documented the importance of adolescents' livelihoods and worked to adapt adult livelihood models to fit adolescents' unique needs. While these programs often share common strategies and elements, all Council adolescent initiatives recognize the need to learn from and adapt to the local context.

\section{Savings options and vocational training benefit girls}

In 2001, the Council teamed with CARE-India to develop a pilot project for girls aged 14-19 in the urban slums of Allahabad, India (Grant, Mensch, and Sebastian 2007), offering vocational training and savings opportunities along with CARE's reproductive health program for slum dwellers. Nearly 500 girls completed at least one of 19 courses, and about 400 girls attended more than one course. When offered the opportunity to start a savings account at local post offices (which offered simpler procedures and required lower initial deposits than banks), more than half the participants opened accounts, despite the unwelcoming attitudes of some of the post office staff. An evaluation of the project found that girls exposed to the intervention were significantly more likely than matched control respondents to have knowledge of safe spaces, to be members of a group, to score higher on indexes of social skills and self-esteem, to be informed about reproductive health, and to spend time on leisure activities (Mensch et al. 2004). This project demonstrated that a vocational training and savings program was not only feasible to implement but also appealing to girls and their parents.

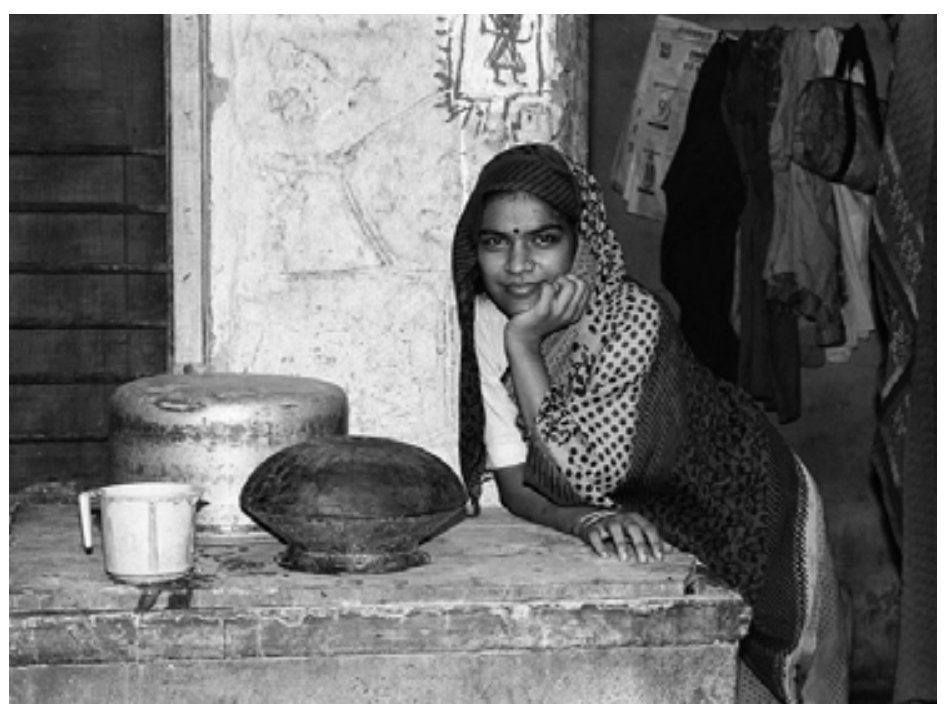

"Adolescent girls' Adventure" offers livelihood skills In Bangladesh, the Council collaborated with the Bangladesh Institute of Development Studies to study a program that offered livelihood skills to 15,000 adolescent girls in three rural districts (Amin 2011). The quasi-experimental project, called Kishori Abhijan ("Adolescent Girls' Adventure"), was implemented by two Bangladeshi NGOs, the Bangladesh Rural Advancement Committee (BRAC) and the Centre for Mass Education in Science. Livelihood skills included life-skills lessons, savings account options, access to credit, and livelihood training (Amin 2011). The project sought to increase girls' age at marriage, enhance their economic activity, and improve their rates of school enrollment, retention, and completion. Delays in marriage, a core objective of the 
project, were achieved by a subgroup of members, namely younger girls from the poorest district who attended school (Amin and Suran 2005). The evaluation also found that participation in Kishori Abhijan increased the number of girls working for cash and supplemented the amount of income they earned. Furthermore, the project demonstrated that working for cash did not lead girls to drop out of school.

A small pilot intervention conducted in 2010 revisited Kishori Abhijan clubs to test a new financial literacy curriculum and demonstrated that focused training to develop these skills can have significant impact on important livelihood skills such as budgeting and savings behaviors. In the process of identifying girls who can serve as mentors, the study team concluded that young women who had been members of the clubs in the past served as a ready pool of eligible mentors to assist in the implementation of financial literacy.

\section{Program success differs by community}

A small qualitative study of a pilot adolescent credit program highlighted the importance of community and context in determining the positive impact of credit initiatives. BRAC offered young girls a credit package that was modeled on its adult credit program. Council researchers observed the implementation of this program in three districts. In Chapainawabganj, where girls are encouraged to participate in the community's quilting tradition, the credit program was well received and empowering. Girls borrowed money to begin their own quilt-making business. In two other districts, Sherpur and Chittagong, where there was no tradition of women's work-force participation, the program did not succeed in empowering adolescent girls to earn their own living. Instead, when loans were taken, the money was handed over to other family members, who were more likely to use the loans for unproductive activities.

\section{Successful adolescent livelihood programs rely on social support}

In many settings, adolescence is a time when the world contracts for girls. Parents increasingly restrict their daughters' lives to the domestic sphere, fearing male attention, the temptation of unsanctioned activities, and the potential damage to their daughters' reputations (Brady 2003). In an effort to expand their world, Council programs create safe, supportive spaces where girls can gather to interact with peers and mentors, strengthen their social networks, and enjoy freedom of expression and movement.

All Council adolescent initiatives share a common strategy: participants are organized into small groups that meet frequently. In the Allahabad project, peer educators formed groups of 15-30 girls who met weekly, usually in the peer educator's home. In the Bangladesh "Kishori Abhijan" project, groups of 20-25 members were led by peer volunteers who provided life-skills training and collected savings weekly. In the Ahmedabad and Vadodara districts in Gujarat, India, the Popula- tion Council collaborated with the Self-Employed Women's Association (SEWA) to implement a project for 13-19-year-old girls that emphasized group formation and agency building (Kalyanwala 2007). Kishori mandals (youth groups) of 15 to 30 girls met two hours a day, three or four times a week to sing, play sports, discuss current events, and participate in awareness sessions on health, nutrition, agriculture, and savings.

Additionally, SEWA offered vocational training courses, along with field trips to the SEWA bank, historical monuments, milk cooperatives, and other civic locations. As evidenced by their regular and sustained attendance and their comments, the girls valued the kishori mandals and developed strong bonds with one another during the 18-month program. Several girls expressed a new facility and willingness to communicate their ideas and knowledge to a wider audience. They developed increased confidence in their ability to handle new experiences. In the words of one participant, "Now I have the courage to talk to [my father]. I can now also talk to the sarpanch [the head of the village]. Earlier I could not talk with anyone."

\section{Recognizing the importance of mentors}

In all Council projects mentors provided skills training and led group activities and discussions. A savings and microcredit project in Nairobi, Kenya discovered through monitoring and evaluation that its social support component had to be augmented in order to meet the needs of girls and young women living in low-income and slum areas (Erulkar et al. 2006). Beginning in 1998, the Population Council collaborated with Kenya Development Agency (KDA), the oldest and largest microfinance institution in Kenya, to implement the Tap and Reposition Youth project (TRY). In the pilot phase, the project model adapted KDA's adult groupbased savings and lending model. Girls met weekly and contributed savings to a group account that eventually constituted collateral for micro-loans. Although girls at first participated actively and loan repayment rates were high, after a time some left the project, and repayment rates began to drop.

Recognizing the precariousness of these girls' lives—unstable living conditions, thin social networks, substantial levels of coerced and transactional sex in an area of high HIV prevalence-TRY's collaborators expanded the social support by adding adult mentors. Mentors provided counseling, organized events, seminars, and day trips, and provided referrals as needed. The girls responded enthusiastically to this new resource. As one girl commented: "This program is very good, even more than the loan. ... There is nothing as good as advice. . . . You could be having a problem, and you don't know who should help you, but when you get someone to discuss it with you, you feel good."

The experience of adolescent livelihood projects to date suggests that while a range of projects is feasible, their success is strongly conditioned by context. In some settings, adolescents can benefit just as much as adults from micro-credit, while in others young people may not be ready 
for savings and loan schemes. In rural Bangladesh, where micro-credit is a household word and almost one-third of adult women belong to microfinance groups, savings and credit schemes for young girls have quickly caught on. Early anecdotal reports from a credit program suggest that adolescent girls are even more adept than their mothers in turning a profit on their loans (personal communication with Harashit Haldar, officer in charge of BRAC's economic-livelihoods-for-adolescents program). Undoubtedly, the collective social learning that resulted from a long history of activities by multiple credit organizations played a part in preparing adolescent girls to take up credit successfully. They graduate to higher loan amounts and accumulate savings quickly and enthusiastically.

In other settings, adolescent girls have found it difficult to take advantage of credit programs. As Kenya's TRY experience demonstrated, the responsibilities and obligations associated with a group-based credit program proved overwhelming for adolescents with little or no preparation to succeed in programs designed for adults. First, adolescents need opportunities to gain financial literacy and to save their money in a safe, accessible place. And while savings opportunities appeared to be the most appropriate financial service for adolescents in Kenya, this was not the case in South Africa, where initial evidence from a livelihood project suggested that having savings before financial education may have increased the vulnerability of young girls in poor communities as friends and family make frequent demands on their savings. Accordingly, the Council and its partners emphasize financial education as the intervention of choice in KwaZulu-Natal. A randomized trial there recently tested the effect of financial education delivered with social support and found it to have positive effects (Hallman et al. 2011).

Ongoing Council projects in Kampala, Uganda, the Kibera slum in Nairobi, Kenya and in KwaZulu-Natal, South Africa are designing and testing financial education curricula tailored to the specific settings and context of adolescents' lives. For example, adolescents in KwaZulu-Natal will learn how to create a budget, develop strategies to pay for their own and their siblings' school fees, access social benefits for which their families might qualify, deal with challenges such as the death of a parent or an unwanted pregnancy, and identify safe and appropriate incomegenerating opportunities. In many of these settings the ability to build assets through better financial management and savings can reduce the need to engage in risky sexual behavior and transactional sex. Financial skills offered along with health education are found to be more effective in promoting healthy behavior than health education alone. In Kenya and Uganda, girls are given a savings diary or a workbook so that they can extend their financial education training in and out of the group setting. These projects serve as examples of how financial education can be integrated into health education program as an essential skill (Austrian and Ngurukie 2009).

In Bangladesh, KwaZulu-Natal, Kibera, as well as in new sites in Kampala, Uganda and throughout Kenya, Council work among adoles- cents will focus on the ability of role models and mentors to enhance the effect of livelihood initiatives. Prior experience suggests some adolescents can learn more effectively through close contact with sameage peers. This appears to be particularly true when success entails challenging traditional structures and adopting innovative behavior to escape poverty.

\section{Summary}

The Council's work on adolescent livelihoods during the past decade has yielded valuable lessons to guide current and future programs. Instead of applying adult programs to adolescents ("junior micro-finance"), programs should consider participants' age, sex, life-cycle stage, and other contextual cues. Social support should be an integral feature of adolescent livelihood programs; a mentoring component can multiply the economic benefits gained. Reaching the most vulnerable adolescents is a continuing challenge because program participants are typically better-off economically, older, attending school, and male. One way to encourage the participation of marginalized young people is to promote a phased model through which entry-level programs provide a safe and supportive space where young people can gather; offer opportunities for individual, voluntary savings; and impart training in life skills, financial literacy, and health education. When they feel ready, adolescents can participate in more demanding options, including goal-oriented savings, vocational and business-skills training, and micro-credit. Such a phased approach may be the most nurturing option and, over time, may prove the most effective. Finally, program planners should not overlook the value of mentors and role models, who can promote positive aspirations among the most marginalized girls.

\section{References and related publications}

Amin, Sajeda. 2011. "Empowering adolescent girls in rural Bangladesh: Kishori Abhijan," Promoting Healthy, Safe, and Productive Transitions to Adulthood Brief no. 13. New York, NY: Population Council.

Amin, Sajeda, lan Diamond, Ruchira T. Naved, and Margaret Newby. 1998. "Transition to adulthood of female garment-factory workers in Bangladesh," Studies in Family Planning 29(2): 185-200.

Amin, Sajeda and Luciana Suran. 2004. "Does dowry improve life for brides? A test of the bequest theory of dowry in rural Bangladesh," Policy Research Division Working Paper \#195. New York: Population Council. «http://www. popcouncil.org/pdfs/wp/195.pdf».

_ 2005. "Program efforts to delay marriage," Paper presented at the XXV International Population Conference of the International Union for the Scientific Study of Population, Tours, France, 18-23 July. <http://iussp2005. princeton.edu/download. aspx?submissionld=52255> . Accessed 3 May 2011.

Austrian, K. and C. Ngurukie. 2009. "Safe and smart savings products for vulnerable adolescent girls in Kenya and Uganda." Youth-Inclusive Financial Services Case Study (No. 3). Washington, DC: Making Cents International. 
Brady, Martha. 2003. "Safe spaces for adolescent girls," in Adolescent and Youth Sexual and Reproductive Health: Charting Directions for a Second Generation of Programming. New York: Population Council and UNFPA, pp.155-176.

Erulkar, Annabel, Judith Bruce, Erica Chong, et al. 2005. "Tap and Reposition Youth (TRY): Providing social support, savings, and micro-credit opportunities for young women in areas with high HIV prevalence," Promoting Healthy, Safe, and Productive Transitions to Adulthood Brief No. 15. New York: Population Council.

Erulkar, Annabel, Judith Bruce, Aleke Dondo, et al. 2006. "Tap and Reposition Youth (TRY): Providing social support, savings, and micro-credit opportunities for young women in areas with high HIV prevalence," SEEDS No. 23. New York: Population Council.

Erulkar, Annabel and Erica Chong. 2005. "Evaluation of a savings and microcredit program for vulnerable young women in Nairobi," New York: Population Council.

Grant, Monica J., Barbara S. Mensch, and Mary P. Sebastian. 2007. "Introducing adolescent livelihoods training in the slums of Allahabad, India," Promoting Healthy, Safe, and Productive Transitions to Adulthood Brief No. 2. New York: Population Council.

Hallman, K. 2005. 'Gendered socioeconomic conditions and HIV risk behaviours among young people in South Africa', African Journal of AIDS Research 4(1): $37-50$.

Hallman, K, K. Govender, E. Mbatha, J. Walsh, R. Pattman, and D. Bhana. 2007. "Social capital, socioeconomic aspirations, and HIV risk behaviors among poor South African youth," Presentation at $3^{\text {rd }}$ South African AIDS Conference, Durban, South Africa.

Hallman K, K. Govender, E. Roca, et al. 2011. "Siyakha Nentsha: Building Economic, Health and Social Capabilities among Highly Vulnerable Adolescents in KwaZulu-Natal, South Africa," Promoting Healthy, Safe, and Productive Transitions to Adulthood Brief No. 4. New York: Population Council.

Jejeebhoy, Shireen and Shveta Kalyanwala. 2007. "Building livelihood skills and opportunities for adolescent girls in India," Transitions to Adulthood Brief No. 18. New York: Population Council.
Kalyanwala, Shweta. 2007. "Influencing girls' lives: Acceptability and effectiveness of a livelihoods skill building intervention in Gujarat," Promoting Healthy, Safe, and Productive Transitions to Adulthood Brief No. 18. New York, NY: Population Council.

Mensch, Barbara S., Monica J. Grant, Mary P. Sebastian, Paul C. Hewett, and Dale Huntington. 2004. "The effect of a livelihoods intervention in an urban slum in India: Do vocational counseling and training alter the attitudes and behavior of adolescent girls?" Policy Research Division Working Paper No. 194. New York: Population Council.

NIPORT and Mitra and Associates. 2001. Bangladesh Demographic and Health Survey 1999-2000. Dhaka and Calverton, MD: NIPORT, Mitra and Associates, and ORC Macro.

Suran, Luciana and Sajeda Amin. 2004. "Does dowry make life better for brides? A test of the bequest theory of dowry in rural Bangladesh," Paper presented at the Annual Meeting of the Population Association of America, Boston, 1-3 April.

\section{Donors}

Department for International Development (DFID)

The Dickler Family Foundation

EMPower-The Emerging Markets Foundation

Focus on Young Adults

The Ford Foundation

Bill \& Melinda Gates Foundation

William H. Kaufman Charitable Foundation

MEASURE Evaluation

The Andrew W. Mellon Foundation

Nike Foundation

The Rockefeller Foundation

The Summit Foundation

Turner Foundation

United Nations Children's Fund (UNICEF)

United States Agency for International Development (USAID)

Effie Westervelt

\section{Population Council}

The Population Council changes the way the world thinks about critical health and development issues. We seek to understand the causes and consequences of gender inequality and the disparities in opportunity that arise during adolescence. We provide the evidence for better on-theground programs and policies that ensure successful and productive transitions to adulthood in developing countries. www.popcouncil.org

(C) 2011 The Population Council, Inc. 